\title{
The Impact of Government Funding on Students' Academic Performance in Ghana
}

\author{
Nurudeen Abdul-Rahaman ${ }^{1}$, Wan Ming ${ }^{1}$, Abdul Basit Abdul Rahaman², Latif Amadu ${ }^{1} \&$ \\ Salma S. Abdul-Rahaman ${ }^{3}$ \\ ${ }^{1}$ University of Science and Technology of China, Hefei, China \\ ${ }^{2}$ Ghana Education Service, Ghana \\ ${ }^{3}$ University of Education, Winneba, Ghana \\ Correspondence: Nurudeen Abdul-Rahaman, University of Science and Technology of China, Hefei, China. Tel: \\ 86-187-5650-1571. E-mail: nurudeenkuberke@gmail.com
}

Received: March 10, 2018

doi:10.5539/ies.v11n7p83

\author{
Accepted: April 15, $2018 \quad$ Online Published: June 28, 2018 \\ URL: https://doi.org/10.5539/ies.v11n7p83
}

\begin{abstract}
High academic performance in senior high education is a significant issue that concerns the government and the people of Ghana because of the huge funding the government provides to schools in the form of progressive free senior high policy. Data starting from 2011/2012 to 2016/2017 academic years were picked from the students' continuous assessment register which contains students' academic records for each academic term. Data were collated and analyzed quantitatively using the Mann Whitney U Test to compare students' academic performance during the period of government partial funding (progressive free policy) from 2014/2015 to 2016/2017 academic years forming a group and no funding period, starting from 2011/2012 to 2013/2014 academic years which formed another group. For the purpose of this study, two groups of twenty (20) students were sampled making forty (40) students in total using the systematic sampling technique. The Mann Whitney $U$ test was used to analyze academic performance of students who benefited from funding and those that do not benefit from funding. The findings indicate that government funding (progressive free policy) has a greater impact on students' academic performance.
\end{abstract}

Keywords: academic performance, government funding, Ghanaians, senior high education

\section{Introduction}

The availability of good quality secondary education is important in generating the opportunities and benefits of social and economic development, World Bank (2005). So, therefore, the academic performance of senior high school students is of paramount interest to governments and parents or guardians worldwide. Ghana as a developing nation with the rapidly rising of state expenditure on senior high school education through progressive free senior high policy (partial funding), public pressure is increasing on public senior high school to show that government expenditures on education maximize students' academic performance. The government of Ghana in the academic year 2014/2015 implemented the progressive free senior sigh education policy to gradually absorbed the cost of education to make it easier for students to transition from the basic junior high level to the senior high levels of education without financial barriers. It is also to increase access and quality to equip Ghanaians with useful skills to ensure that all citizens acquire the basic skills needed to function well and take up proactive roles in their societies that would propel the country's economy from Middle-income to High-income status. The funding provided to schools by the government covers the cost of the examination, entertainment, library, Student Representative Council dues, sports, culture, science development and mathematics quiz, Information Communication Technology, co-curricular fees. The main theme addressed in this study is to examine the impact of government funding (partial funding) on the performance of students in the Wa Municipality of the Upper West Region of Ghana. Wa Senior High School was chosen for the study because it was upgraded into a model school in the Wa Municipality and that implies that special attention has been given to this institution in terms of government funding in the form of progressive free policy. In line with this, much attention has been shifted by the people of Ghana to the senior high education because of the increase in government funding to senior high schools and the impact of government funding on students' academic performance is key to analyzing the government policy considering learning outcomes. The study adopted the quantitative method to collect and analyze data. The data 
was drawn from student's continuous assessment register that contains academic performance on termly bases and each academic year consist of three terms.

Taken into consideration the huge amount of governments funding to schools, no wonder some literature detailing the effectiveness of governments funding on the academic performance of students. Some of these studies have found funding to be useful in improving the academic performance of students and some have not seen a positive significant impact of funding on students' academic achievement.

A study conducted by Jones and Moss (1994) shows a major difference in academic performance between need-based aid beneficiaries and students that do not receive any aid among medical students.

Brock and Richburg-Hayes (2006) looked at the impact of a Louisiana needs-based scholarship program on course completion and exam score of students of low-income parents attending community college. Students were randomly selected from a treatment and control group. Those in the control group were given financial aid and the others in the treatment group were given $\$ 2000$ in scholarship per annum if they participated in school at least half-time and achieved average a grade $\mathrm{C}$. Both groups were counseled before given the aid and the program resulted in multiple positive outcomes in students' learning.

Also, Carlson CW. (2006) in a different study indicates that Need-based financial aid beneficiaries do not perform lower (measured by Grade Point Average) as compared to students who receive no need-based aid and found that, need-based aid beneficiaries had higher academic performance levels when compared to students who did not benefit from need-based aid.

In addition, Institutional scholarships to students significantly affected student success across all measures: hours attempted, hours earned, and graduation within six years of entry (Natasha M et al. 2011).

Belot et al. (2007) use the huge reforms that occurred in the Dutch student's support system to assess the impact of financial aid on students' academic attainment and time allocation. The grants period was limited by a year in 1996. Their study indicates that students attained higher grade after the reform was made.

Stater (2009), after controlling for various demographic and background characteristics of students, indicated that, both need-based and merit-based had a positive impact on Grade Point Average (GPA), even though the effects were stronger for merit-based aid than need-based aid.

Angrist et al. (2009), after using a randomized control trial (RCT) evaluation of a program to test whether academic supports to students and merit-based scholarships improved academic performance in a Canadian university. The study resulted in 2-3\% increase in GPA (grade point average) mostly for women that lasted more than a year and a reduction of $6.9 \%$ in the proportion of students that were on academic probation.

Also, one study finds that high schools that are well-endowed with abundant resources had a positive significant effect on the scores of their first-year college students (Wolniak \& Engberg, 2010).

In a similar pursuit, the ACCESS program led to significant improvements in students' academic performance in Ireland (Denny et al., 2014).

Blimpo et al. (2015) look at the effects of Gambian female scholarship program on the academic performance of secondary school students. Their research resulted that the program increase test scores of English Language and Mathematics.

Also, aid lead to the increase in enrollment rates, the decrease in dropout rates, and the improvement of academic performance in a significant and a sizeable magnitude (Tatiana et al., 2016).

However, there had been a number of studies that do not agree with the above studies. Douglass and Gregg (2012) studied the effects of financial aid on students' grade points at research institutions. They find that Pell Grant recipients, on average, studied one hour longer than other students but still earned lower grades.

Studies in other settings have found no statistically significant correlation between financial aid and academic performance once controls for demographics and earlier academic performance were introduced (Hoffman, 2002; Scott-Clayton, 2011).

Erik and Andreas (2010) use the regression-discontinuity approach and did not find a systematic impact of loans on academic performance, possibly because the exploited changes in credit assignment are rather small.

Arcidiacono (2005) examines how financial aid policies contribute to a student's decision to matriculate with a given university and their future earnings. The study focuses on students of the black race and finds that although there is a significant effect of financial aid on graduating blacks from college, there is also a little effect on earnings from race-based more aid beyond the standard amounts. 
Weaver (2013), after conducting a study did not see any significant relationship between financial responsibility, motivation, and academic success of students in college.

Also, Elizabeth and John (2015), after using the regression analyses show that both GPA and the percentage of units completed have small, statistically significant negative relationships with the amount of aid received per unit after controlling the effects of gender, age, and the number of units attempted.

Furthermore, the Gates Millennium Scholars Program does seem to have a positive effect on a few academic and social engagement behaviors of recipients but the evidence which support the fact the G.M.S influenced college GPA (grade point average) is weak (Angea \& Bridget 2016).

Having looked at earlier studies on the study topic, there had not been any study addressing the topic government funding (progressive free policy) on students' academic performance at the senior high level. Most of the studies are on government capitation grant to basic schools. This study checks the impact of government partial funding (progressive free policy) on students' academic performance in the Wa Municipality of Ghana.

The paper then proceeds to the method used to carry out the study, data analysis, results, discussion, conclusion.

\section{Method}

Secondary data were collected from the student's continuous assessment registers at Wa Senior High School which contain records of students' academic performance for the three years and each academic year consisting three terms. The Statistical Package for Social Science (SPSS) software was employed as a tool in the data analysis. Data starting from 2011/2012 to 2016/2017 academic years were collated and analyzed quantitatively using the Mann Whitney U Test to compare students' academic performance during the period of government partial funding (progressive free policy) from 2014/2015 to 2016/2017 academic years forming a group and no funding period, starting from 2011/2012 to 2013-2014 academic years which formed another group. For the purpose of this study, two groups of twenty (20) students were sampled for each group making forty (40) students in total using the systematic sampling technique. The Mann Whitney $U$ test was used to analyze data because it is a non-parametric test that does not need the data to be normally distributed. Wa Senior High was chosen for the study because it was upgraded into a model school in the Municipality.

The hypotheses proposed in this study are;

$H_{0}$ : The mean performance of English language, Integrated Science, Mathematics, and Social Studies are the same across categories of all years.

$H_{1}$ : The mean performance of English language, Integrated Science, Mathematics, and Social Studies are not the same across categories of all years.

\section{Results}

The academic performance data was picked from student's continuous assessment registers. Academic performance scores for every student per every term were picked to get the average performance of each student for their three years of stay in school. Table 1 gives a description of the mean performance of the two groups of students. It reveals that students who graduated in 2017 performed better averagely thus sixty-six (66) in Mathematics than 2014 graduates' average performance which is forty-nine (49). The Table further reveals that students who graduated in 2017 performed better averagely in the rest of the subjects. That is Integrated Science graduates recorded sixty-eight (68) against fifty (50), seventy (70) against fifty-two (52) in the English language, seventy-two (72) and against fifty-seven (57) in Social Studies for 2017 and 2014 respectively. All in favor of graduate in 2017 which is illustrated in Table 1. 
Table 1. Descriptive Statistics of Mean performance of students by subjects in 2014 and 2017

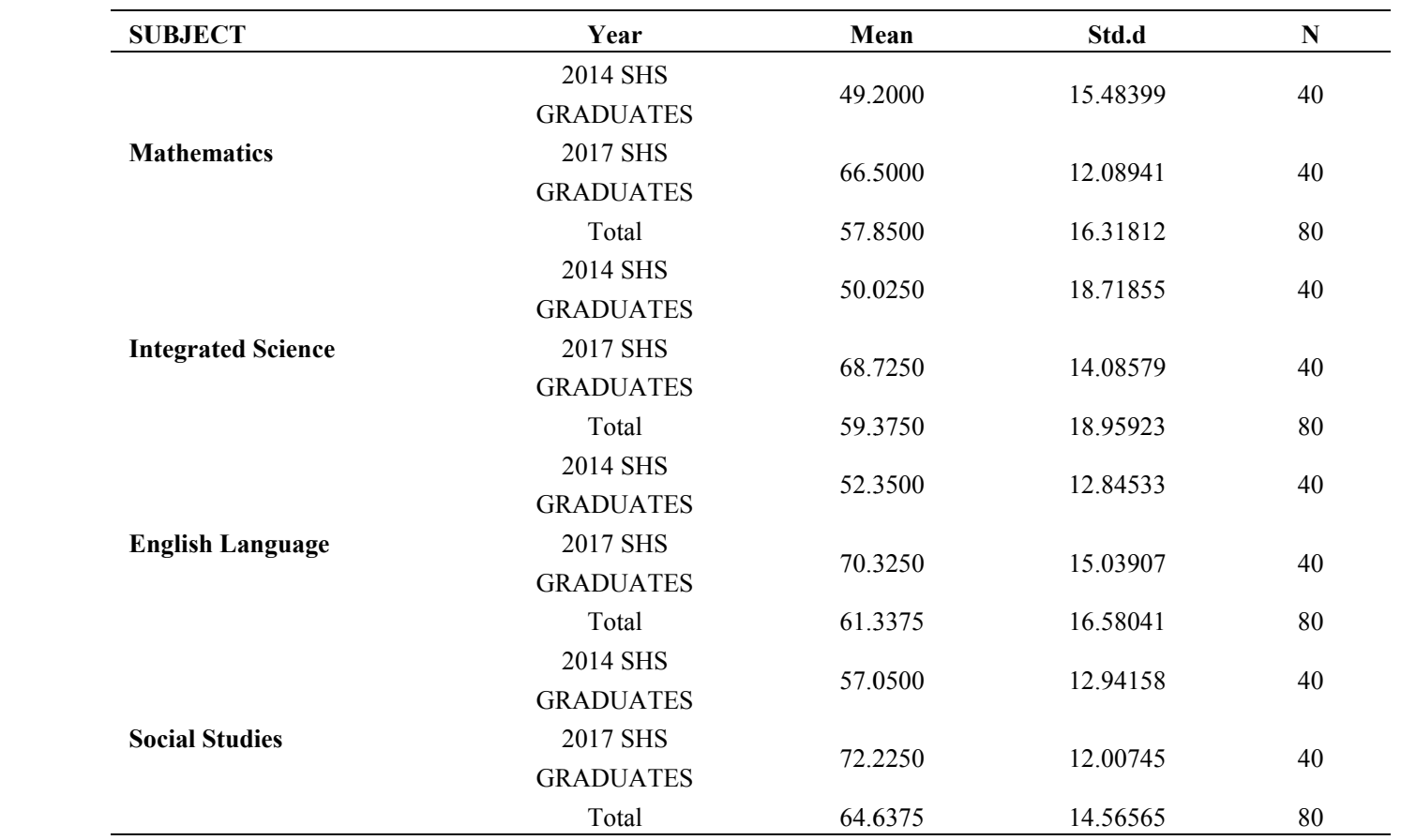

Note. Std.d = Standard deviation, $\mathrm{N}=$ number, S.H.S = Senior High School.

Figures 1, 2, 3, 4 and 5 compare the academic performance of two groups of 40 students. Senior High School Graduates in 2014 (no funding) and 2017 graduates with government partial funding (progressive free students).

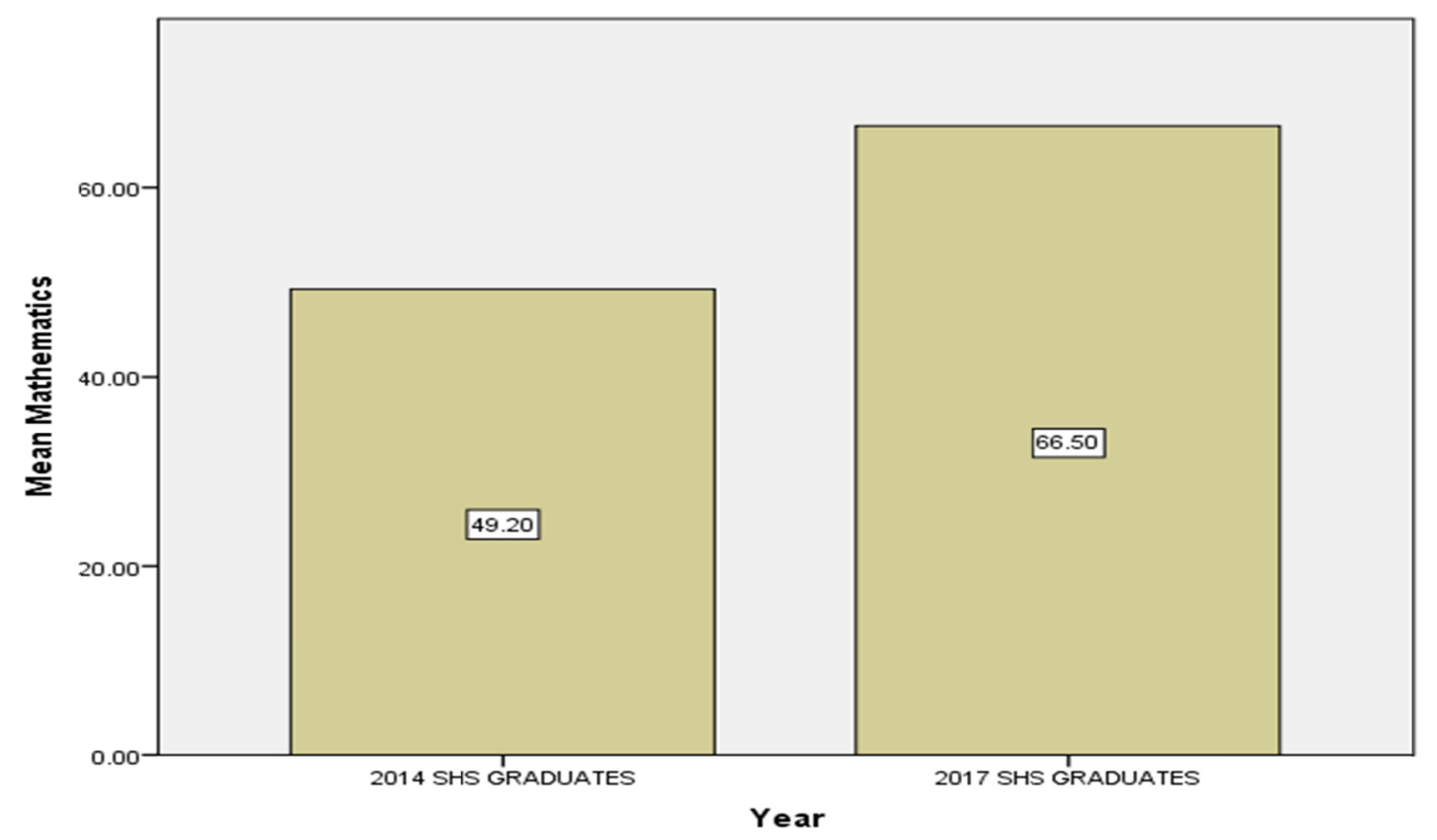

Figure 1. The mean performance of students in Mathematics in 2014 and 2017 


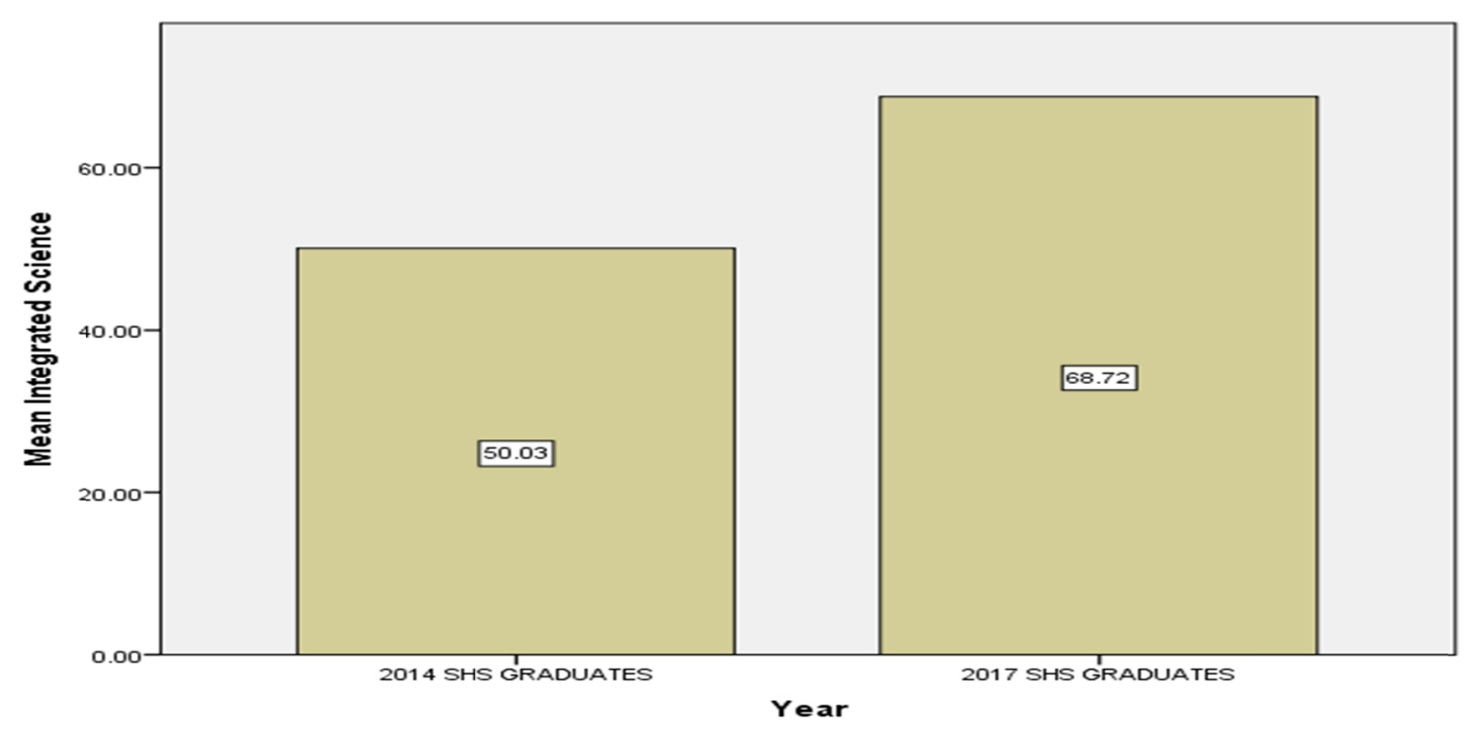

Figure 2. The mean performance of students in Integrated Science for 2014 and 2017.

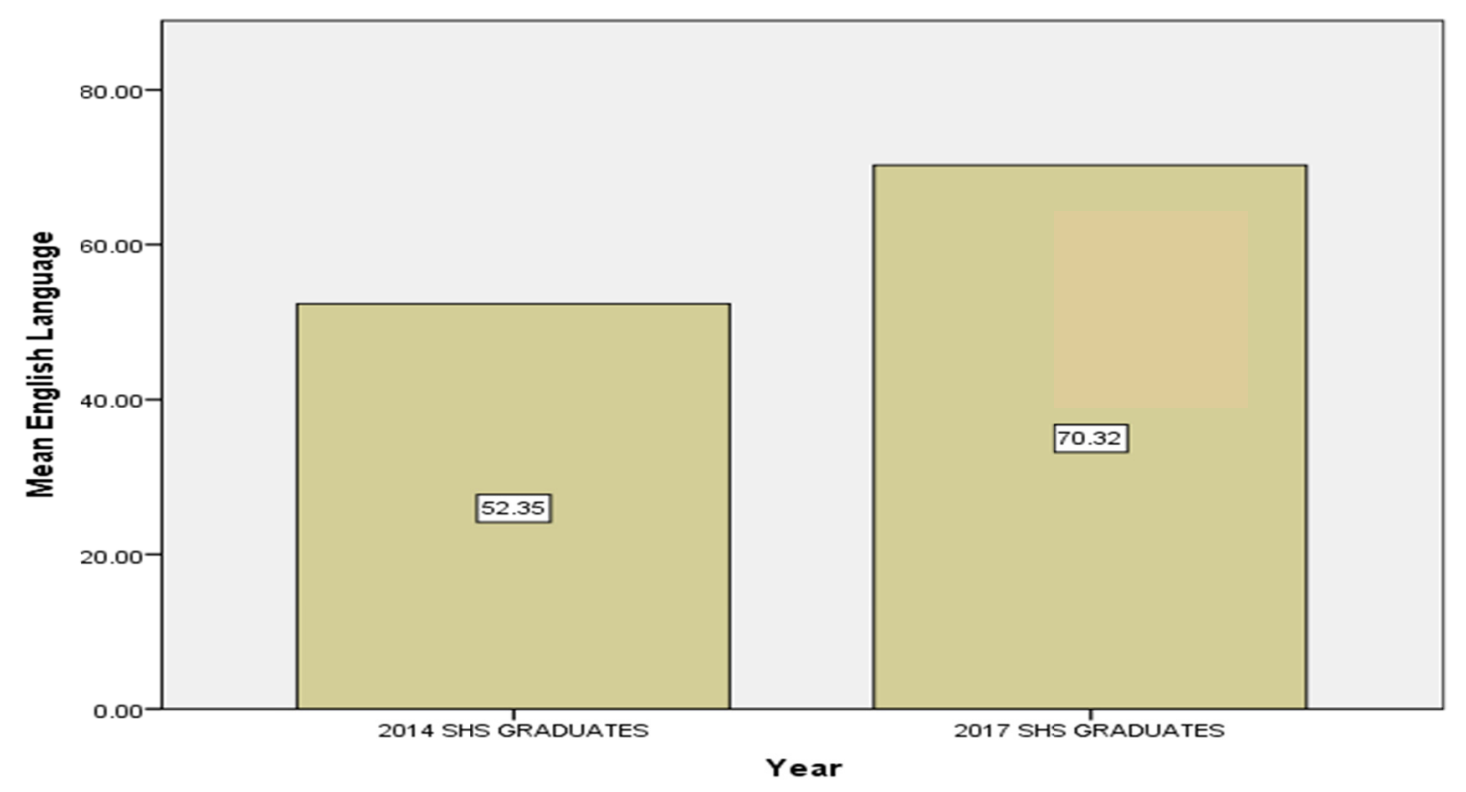

Figure 3. The mean performance of students in the English Language for 2014 and 2017 


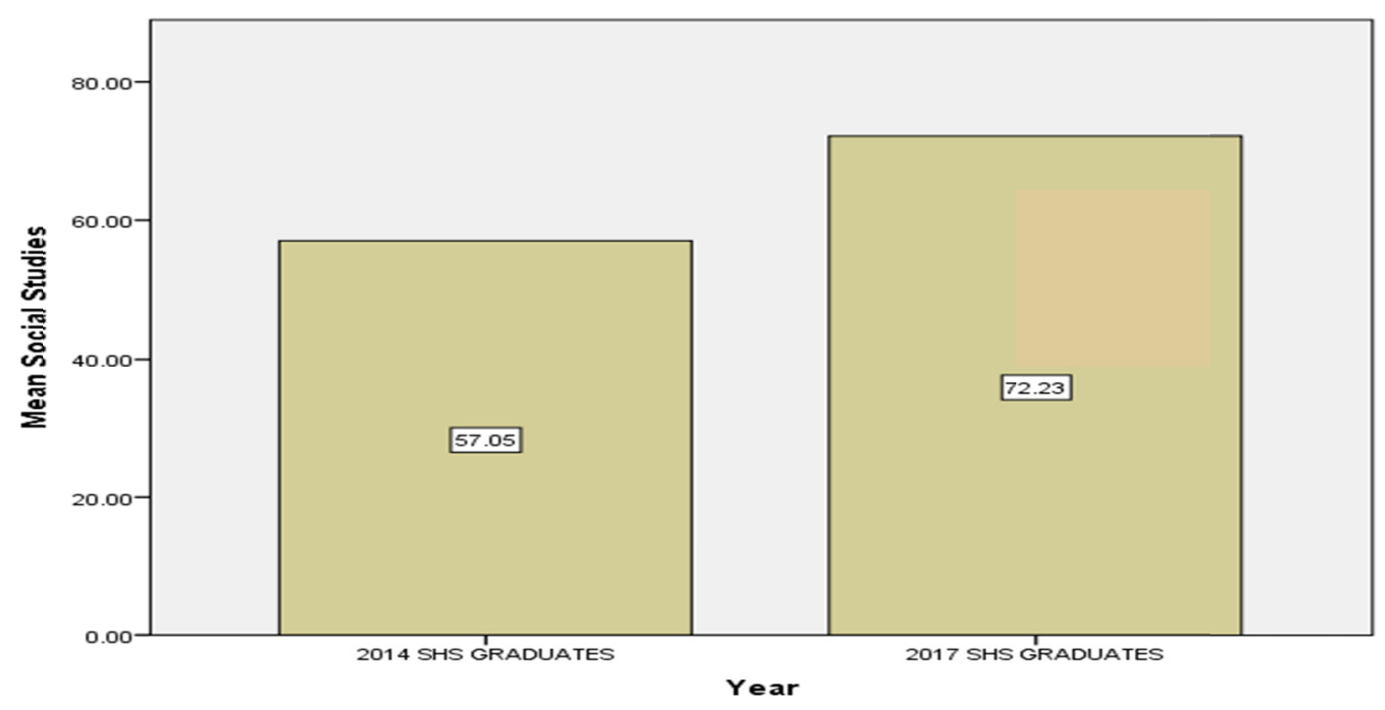

Figure 4. The mean performance of students in Social Studies for 2014 and 2017

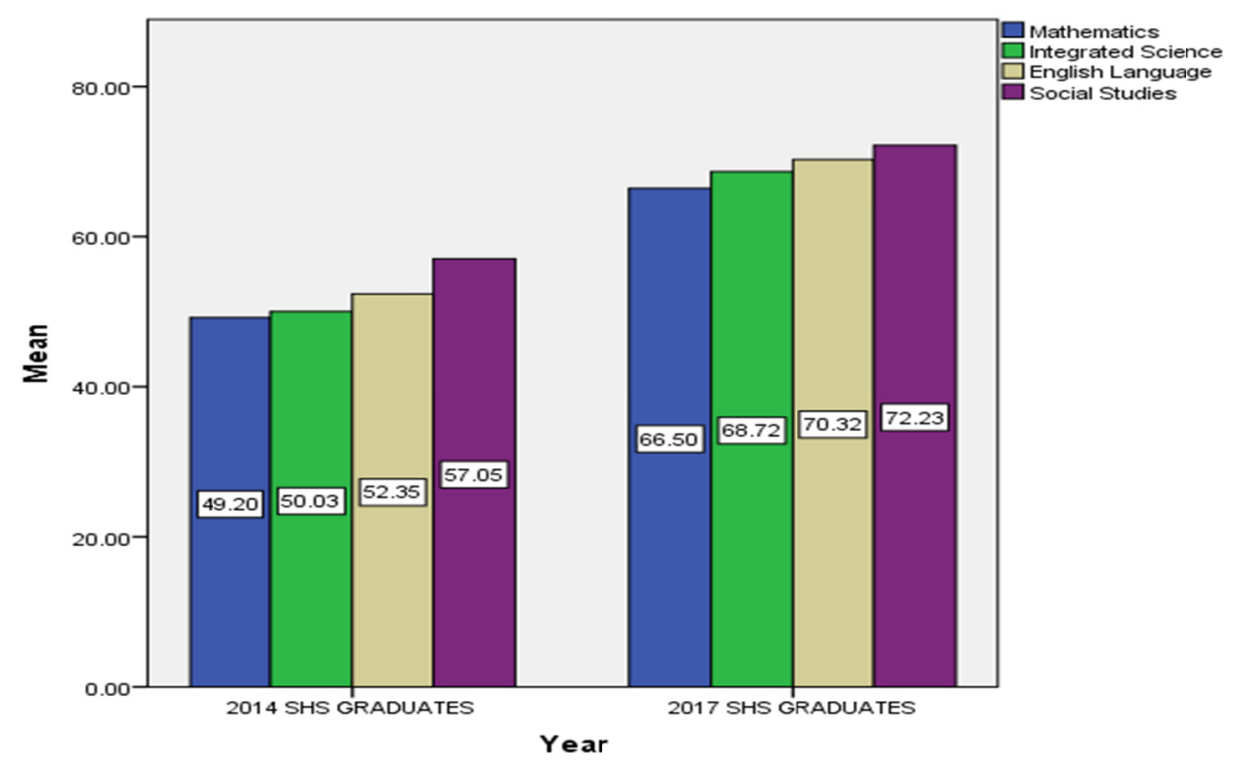

Figure 5. Shows the compared academic performance of students in all subjects in 2014 and 2017 year groups

Table 2. Hypothesis test summary/result

\begin{tabular}{|c|c|c|c|}
\hline Null Hypothesis & Test & Sig. & Decision \\
\hline $\begin{array}{l}\text { The distribution of Mathematics is the same across categories of } \\
\text { the year. }\end{array}$ & $\begin{array}{c}\text { Independent sample of Mann Whitney } \\
\text { U test }\end{array}$ & .000 & $\begin{array}{l}\text { Reject the Null } \\
\text { Hypothesis. }\end{array}$ \\
\hline $\begin{array}{l}\text { The distribution of English is the same across categories of the } \\
\text { year. }\end{array}$ & $\begin{array}{c}\text { Independent sample of Mann Whitney } \\
\text { U test }\end{array}$ & .000 & $\begin{array}{l}\text { Reject the Null } \\
\text { Hypothesis. }\end{array}$ \\
\hline $\begin{array}{l}\text { The distribution of Social studies is the same across categories of } \\
\text { the year. }\end{array}$ & $\begin{array}{l}\text { Independent sample of Mann Whitney } \\
\text { U test }\end{array}$ & .000 & $\begin{array}{c}\text { Reject the Null } \\
\text { Hypothesis. }\end{array}$ \\
\hline $\begin{array}{l}\text { The distribution of Integrated Science is the same across } \\
\text { categories of the year. }\end{array}$ & $\begin{array}{l}\text { Independent sample of Mann Whitney } \\
\text { U test }\end{array}$ & .000 & $\begin{array}{l}\text { Reject the Null } \\
\text { Hypothesis. }\end{array}$ \\
\hline
\end{tabular}

The Significance level is .05 . 
The Mann Whitney U Test is used to test the following hypotheses.

\section{Test of hypothesis 1 .}

$H_{0}$ : The mean performance of mathematics is the same across categories of all years.

$H_{1}$ : The mean performance of mathematics is not the same across categories of all years.

The year categories include 2014 graduates and 2017 graduates. Table 2 indicates that the alpha value is greater than the significant value $(0.05>0.00)$ hence we fail to accept the null hypothesis. This informs us that there exists a highly significant difference in the average performance of mathematics across the year category. This can be observed in Table 1 as it indicates that the average performance of mathematics in 2017 is higher than that of the 2014-year group. Inferences, therefore, can be drawn that government funding in the form of progressive Senior High School has greatly impacted on students' academic performance.

Test of hypothesis 2.

$H_{0}$ : The mean performance of English language is the same across categories of all years.

$H_{1}$ : The mean performance of English language is not the same across categories of all years.

Table 2 shows that the alpha value is higher than the significant value $(0.05>0.00)$ hence we fail to agree with the null hypothesis. This tells us that there exists a highly significant difference in the average performance of English language across the year category. This can be observed in Table 1 as it indicates that the average performance of English language in 2017 is higher than that of the 2014-year group. Conclusion, therefore, can be drawn that the progressive senior high school (government partial funding) has greatly impacted positively on students' academic performance.

Test of hypothesis 3.

$H_{0}$ : The mean performance of Social Studies is the same across categories of all years.

$H_{1}$ : The mean performance of Social Studies is not the same across categories of all years.

Table 2 indicates that the alpha value is greater than the significant value $(0.05>0.00)$ hence we fail to accept the null hypothesis. This informs us that there exists a highly significant difference in the average performance of Social Studies across the year category. This can be seen in Table 1 as it indicates that the average academic performance of Social Studies in 2017 is higher than that of the 2014-year group. Inferences, therefore, can be made that the progressive Senior High School (government funding) has greatly impacted positively on students' academic performance.

\section{Test of hypothesis 4.}

$H_{0}$ : The mean performance of Integrated Science is the same across categories of all years.

$H_{1}$ : The mean performance of Integrated Science is not the same across categories of all years.

Table 2 indicates that the alpha value is greater than the significant value $(0.05>0.00)$ and so, therefore, we fail to accept the null hypothesis. This informs us that there exists a highly significant difference in the average performance of Integrated Science across the year category. This can be seen in Table 1 as it indicates that the average performance of Integrated Science in

2017 is higher than that of the 2014-year group. We can then conclude that government funding in the form of the progressive Senior High School policy has greatly impacted positively on students' academic performance.

After testing the hypothesis, the overall result is that government funding in the form of progressive free senior high school policy has a major impact on students' academic performance in all the four (4) core Subjects taught in senior high schools in the Wa Municipality of the Upper West Region of Ghana.

\section{Discussions}

The results of the study the impact of government funding on students' academic performance show that government funding in the form of progressive free senior high school policy has a significant effect on students' academic performance in Schools in the Wa Municipality of the Upper West Region of Ghana.

As indicated in the above result, the mean performance of students in all the compulsory subjects taken in senior high schools of both groups under study is as follows: Mathematics recorded sixty-six (66) against forty-nine (49), sixty-eight (68) against fifty (50) in Integrated Science, seventy (70) against fifty-two (52) in the English language, seventy-two (72) against fifty-seven (57) in Social Studies for 2017 and 2014 respectively. In addition, on the hypotheses, each has a significant value of 0.00 compared to an alpha value of 0.05 . Hence we fail to accept all the 
null hypotheses.

There was a significant difference in performance of graduates in 2017 that enjoyed government partial funding than students that do not benefit from government partial funding (progressive free policy) because students do not have to worry much about fees as part is being paid by the government and this increases their concentration during studies. This result is in line with the findings (Jones \& Moss, 1994; Brock \& Richburg-Hayes, 2006; Carlson CW.,2006; Natasha et al., 2011; (Belot et al., 2007; Stater, 2009; Angrist et al., 2009; Wolniak \& Engberg, 2010; Denny et al., 2014; Moussa et al., 2015; Tatiana et al., 2016). However, this study is contrary to the findings (Douglass \& Gregg, 2012; Hoffman, 2002; Scott-Clayton, 2011; Erik \& Andreas 2010; Arcidiacono, 2005; Amber EW., 2013; Elizabeth \& John, 2015; Angea \& Bridget, 2016).

We can say government of Ghana funding in the form of progressive free policy has improved the quality of educational outcomes at the senior high level in the Wa Municipality. This would equip students with useful skills to make sure that all acquire the basic needed skills to function well and take up proactive roles in their societies that would propel the country's economic growth and development. The result indicated would help reduce public pressure on senior high schools in the Municipality.

\section{Conclusion}

The purpose of this study was to add to the growing literature on the effect of funding on students' academic performance. The Study uses secondary data on students' performance of Wa Senior High School to compare the period of no-aid and the period of government partial funding in the form of progressive free policy on students' academic performance. The result shows that students' academic performance in all four compulsory subjects such as Mathematics, Integrated Science, English Language, and Social Studies improved significantly during government partial funding (progressive free policy). The null hypotheses for the four subjects were rejected in this study. To sum it up, the government of Ghana funding in the form of progressive free education has improved students' academic performance in the Wa Municipality of Ghana. Unfortunately, the study had data limitation as the final exams conducted by the West African Examination Council (WAEC) which is an external body at the end of the three years' duration in school performance scores was not added and checked because it was not readily available at the time of the study. So, therefore, future study should add the final West African Examination Council (WAEC) exam score to compare the impact of government funding on students' academic performance.

\section{Recommendation}

The study suggested some recommendation based on the result of the study.

1) A future study comparing the academic performance of students under progressive free and the current free education policy which started in 2017.

2) The government must make sure there is a reliable source of funding to senior high schools.

3) The government must release funding to schools in time.

4) A frequent audit of government funding to senior high schools to make sure is meeting the intended needs and requirements.

5) The replication of this same study among other senior high schools around the country

6) Teachers of senior high schools must be motivated to teach students to maximize performance by given them higher salaries and free housing among others.

7) Adequate teaching and learning materials must be provided to senior high school often.

8) Schools must put mechanisms in place to helping students in selecting courses during their enrollment to senior high schools to make sure that students fit into their various course areas.

9) Schools with boarding facilities must ensure that students are fed with nutritious and healthy food to keep them active to face up their studies.

\section{Acknowledgements}

The authors received financial support from a friend called Julie Didlick from Australia. She also assisted in editing the grammar of the manuscript.

\section{References}

Angrist J., Lang, D., \& Oreopoulos, P. (2009). Incentives and services for college achievement: Evidence from a randomized trial. American Economic Journal and Applied Economics, 1(1), 136-163. https://doi.org/10.1257/app.1.1.136 
Arcidiacono, P. (2005). Affirmative Action in higher education: How do admission and financial aid rules affect future earnings? Journal of the Econometric Society, 73(5), 1477-1524. https://doi.org/10.1111/j.1468-0262.2005.00627.x

Belot, M., Canton, E., \& Webbink D. (2007). Does reducing student support affect scholastic performance? Evidence from a Dutch reform. Empirical Economics, 2(2), 61-75. https://doi.org/10.1007/s00181-006-0094-1

Carlson, C. W. (2006). Academic performance of students who receive need-based financial aid.

Denny, K., Doyle, O., McMullin, P., \& O’Sullivan, V. (2014). Money, mentoring and making friends: The impact of a multidimensional access program on student performance. Economics of Education Review, 40, 167-182 https://doi.org/10.1016/j.econedurev.2014.03.001

Douglass, J., \& Gregg, T. (2012). Poor and rich: student economic stratification and academic performance in a public research university system. Higher Education Quarterly, 66(1), 65-89. https://doi.org/10.1111/j.1468-2273.2011.00511.x

Elizabeth, C., \& John, L. H. (2015). Financial aid tipping points: an analysis of aid and academic achievement at a California Community College. Community College Journal of Research and Practice.

Erik, C., \& Andreas, B. (2010). Student support and academic performance: experiences at private universities in Mexico. Education Economics, 18(1), 49-65. https://doi.org/10.1080/09645290801931766

Hoffman, J. L. (2002). The impact of student co-curricular involvement on student success: Racial and religious differences. The Journal of College Student Development, 43(5), 712-739.

Jones, B., \& Moss, P. (1994). The influence of financial aid on academic performance and persistence in medical school. The Journal of Student Financial Aid, 24(3), 5-11.

Long, A. B., \& Terry, L. B. (2016). Does financial aid impact college student engagement? Evidence from the Gates Millennium Scholars Program.

Melguizo, T., Torres, F. S., \& Velasco T. (2016). Credit for low-income students and access to academic performance in higher education in Colombia: A regression discontinuity approach. World Development, 80, 61-77. https://doi.org/10.1016/j.worlddev.2015.11.018

Moussa, P. B., Gajigo, O., \& Pugatch, T. (2015). Financial constraints and girls'secondary education: Evidence from school fee elimination in The Gambia.

Natasha, M. G., \& Michelle, M. (2011). The Relationship between scholarships and student success: An art and design case study.

Scott-Clayton, J. (2011). The causal effect of federal work-study participation: Quasi-experimental evidence from West Virginia. Educational Evaluation and Policy Analysis, 33(4), 506-527. https://doi.org/10.3102/0162373711421211

Stater, M. (2009). The Impact of financial aid on college GPA at three flagship public institutions. American Educational Research Journal, 46(3), 782-815. https://doi.org/10.3102/0002831208329903

Thomas, B., \& Lashawn, R (2006). Paying for persistence early results of a Louisiana scholarship program for low-income parents attending community college.

Weaver, A. E. (2013). The relationship between students' financial responsibility for college and levels of academic motivation and success.

Wolniak, G. C., \& Engberg, M. E. (2010). Academic achievement in the first year of college: Evidence of the pervasive effects of the high school context. Research in Higher Education, 51(5), 451-467. https://doi.org/10.1007/s11162-010-9165-4

World Bank. (2005). Expanding opportunities and building competencies for young people: A new agenda for secondary education.

\section{Copyrights}

Copyright for this article is retained by the author(s), with first publication rights granted to the journal.

This is an open-access article distributed under the terms and conditions of the Creative Commons Attribution license (http://creativecommons.org/licenses/by/4.0/). 